\title{
PENNSYLVANIA CHATTEL SECURITY AND THE UNIFORM COMMERCIAL CODE
}

\section{By Marvin Schwartz $\dagger$}

The Pennsylvania lawyer who looks at secured commercial transactions in the light of Article 8 of the proposed Uniform Commercial Code may well feel that he is really seeing them for the first time. Business men have for centuries relied upon security interests to protect extensions of credit, but lawyers have become accustomed to thinking of these transactions in terms of bailment, chattel mortgage, trust receipt, etc., because under the law of Pennsylvania as it is today, a secured transaction has no legal existence except insofar as it is capable of being fitted into one of the legally recognized forms. Under the Code, businessmen will continue to extend credit on the strength of security interests and in almost every case will be no more or no less secure than they were before. But lawyers will no longer have to squeeze transactions shaped by the twentieth century business needs of their clients into a form that was cast to satisfy the requirements of a bygone age. The end result will, in most cases, be the same under the Code as it was before, but it will be easier and therefore cheaper to get there.

By way of introduction, this paper will attempt to evaluate the impact of the Code upon secured transactions in Pennsylvania. It will, therefore, be principally concerned with Article 8 of the Code, entitled "Secured Transactions." The Code, as revised to October, 1949, contains nine Articles in all, ${ }^{,}$and it is that draft which will be discussed here. Some changes will be made, however, at the joint meeting in May, 1950, of the American Law Institute and the National Conference of Commissioners on Uniform State Laws. ${ }^{2}$ It is expected that the Code will be presented to the 1951 session of the General Assembly.

Article 8 itself is divided into five parts: applicability and definitions; validity of a security agreement and the rights of the parties

†L. B., 1949, University of Pennsylvania; Member of the Philadelphia Bar.

1. Article 1, General Provisions; Article 2, Sales; Article 3, Commercial Paper; Article 4, Letters of Credit; Article 5, Foreign Banking; Article 6, Documents of Title; Article 7, Investment Securities; Article 8, Secured Transactions; Article 9, Bulk Sales. The article on bulk sales is substantially the same, except for marked improvements in language and form, as the Pennsylvania Bulk Sales Law, PA. Stat. ANN., tit. 69, $\$ \$ 521-529$ (Purdon, 1931 ; Cum. Supp. 1948); Pa. Laws 1919, No. 141, pp. 262-265, as amended to date by Pa. Laws 1939, No. 97, pp. 189-190.

2. For the history of Uniform Commercial Code, see Beers, The New Commercial Code, 2 Bus. LAw 14 (1947); Goodrich, Modern Law for Modern Business, 49 CoM. L.J. 148 (1944), Nation's Business, March, 1944, p. 23; Ireton, The Proposed Conmercial Code: A New Deal in Chattel Security, 43 ILr. L. REv. 794 (1949). 
thereto; rights of purchasers from and creditors of the debtor; formalities of filing; and rights on default. It would supplant and require the repeal of six Pennsylvania statutes of general applicability ${ }^{3}$ and would make it advisable to amend three others. ${ }^{4}$

Whether a secured transaction takes the form, for instance of a bailment lease or a chattel mortgage should be of no significance under the Code. What will be significant is whether the goods involved are consumer goods, inventory or equipment. ${ }^{5}$ To illustrate, the retailer who sells a refrigerator on credit under present law may protect his interest by employing a bailment lease, a conditional sale contract or a chattel mortgage. ${ }^{5 a}$ He must make a perfect choice, and at his

3. Act of June 28, 1947 (bailment leases), Pa. Stat. ANN., tit. 69, $\$ \$ 511-514$ (Purdon, Cum. Supp. 1948) ; Pa. Laws 1947, No. 478, pp. 1141-1142.

Factor's Lien Act, Pa. Stat. Ann., tit. 6, \$§221-229 (Purdon, Cum. Supp. 1948); Pa. Laws 1947, No. 241, pp. 529-533.

Act of June 1, 1945 (chattel mortgages), Pa. Stat. Ann., tit. 21, \$940; Pa. Laws 1945, No. 434, pp. 1358-1366, as amended to date by Pa. Laws 1947, No. 461, pp. 1070 1071 ; Pa. Laws 1947, No. 110, pp. 270-272.

Act of July 31, 1941 (transfer of accounts receivable), PA. Stat. Ann., tit. 69, $\$ \S 561-563$ (Purdon, Cum. Supp. 1948) ; Pa. Laws 1941, No. 255, pp. 606-607.

Uniform Trust Receipts Act, PA. Stat. AnN., tit. 68, \$\$ 551-570 (Purdon, Cum. Supp. 1948) ; Pa. Laws 1941, No. 138, pp. 307-317. ..

Uniform Conditional Sales Act, Pa. Stat. Ann., tit. 69, $\$ \$ 361-504$ (Purdon, 1931, Cum. Supp 1948); Pa. Laws 1925, No. 325, pp. 603-612, as amended to date by Pa. Laws 1935, No. 239, pp. 658-660; Pa. Laws 1939, No. 37, pp. 43-44; Pa. Laws 1943, No. 174, p. 373; Pa. Laws 1947, No. 477, pp. 1140-1141; Pa. Laws 1949, No. 109.

\section{Statutes applicable to special types of collateral:}

Act of March 7, 1929 (mortgage of vessels), PA. Stat. Ann., tit. 21, \$\$ 921-930 (Purdon, 1930); Pa. Laws 1929, No. 12, pp. 14-17.

Act of May 13, 1889 (mortgage of royalties from mineral lands), Pa. Stat. Ann., tit. 21, \$\$ 891-894 (Purdon, 1930); Pa. Laws 1889, No. 217, pp. 197-198.

Act of April 28, 1887 (mortgage of enumerated iron and petroleum products), Pa. Stat. AnN., tit. 21, $\$ \$ 81-870$ (Purdon, 1930) ; Pa. Laws 1887, No. 32, pp. 7375, as amended by Pa. Laws 1891, No. 78, p. 102.

4. See text at notes $15,34,52$, infra.

5. \$ 8-107. "In this Article goods subject to a security interest are

"(1) 'consumer goods' if they are used for the debtor's personal, family or household purposes; or if they are goods not otherwise included in the definitions of inventory, farm products or equipment;

"(2) 'equipment' if used by a debtor in his business or calling or if used in farming or if used by a debtor who is a non-profit organization or a governmental subdivision or agency. Equipment includes machinery whether or not affixed to the realty, rolling stock, vehicles and craft but does not include goods which at the time a security interest attaches are being held or prepared for sale in the ordinary course of the debtor's business;

"(3) [crops, livestock and farm products] . . .;

“(4) 'inventory' if the debtor is a manufacturer, processor, dealer or other person holding or preparing the goods for sale or furnishing the goods as part of a contract of services and if the goods are raw materials, materials in course of manufacture or processing, materials consumed in the business and finished goods."

Section references in this paper are to the Uniform Commercial Code, unless otherwise indicated.

5a. It has been suggested that the chattel mortgage statute covers only loans and not sales transactions. Berger, War Time and Post War Pennsylvania Contracts, Decisions and Statutes, 95 U. of PA. L. Rev. 30, 45-47 (1946) ; Mulder, The Penn- 
peril, for as will be discussed below, a mistaken choice under certain circumstances may mean the complete loss of his security interest. If he merely "leases" the refrigerator, there is no requirement that there be a public record of the transaction. "If the "lease" so provides, he may repossess upon default and do with the used refrigerator as he pleases. ${ }^{7}$ No disposition of the refrigerator by the "lessee" can cut off the dealer's interest and the dealer is fully protected against creditors. ${ }^{8}$ If, however, the dealer employs the chattel mortgage or conditional sale device to protect his interest, he must file a copy of the security instrument. The seller is protected against the purchaser's creditors and subsequent vendees, but if he repossesses he must follow the rather elaborate procedure ordained by the legislature. The Code, on the other hand, recognizes what lawyers have known for a long time: the factual situation remains the same whether the security device employed is a bailment lease, chattel mortgage or conditional sale. Therefore, it treats the transaction the same no matter what the parties choose to call it. In effect it is the Code which makes the choice of security device, not the lender, and the danger of a mistaken choice is obviated. If the requirements of all concerned are satisfied by a bailment lease, for which filing is not required, why require filing for the same transaction merely because it bears a different label? If the chattel mortgagor and the conditional vendee must be protected against harsh repossession practices, why not the lessee under a bailment lease?

To take another illustration, the statutory chattel mortgage may be used in any number of situations. It may protect the retail seller of a washing machine, the supplier of seed to a farmer, the seller of industrial or farm equipment, or the lender who finances the acquisi-

sylvania Chattel Mortgage Act, 17 PA. B.A.Q. 242 (1946); Note, The Priority Provision of the Pennsylvania Chattel Mortgage Act, 95 U. of PA. L. Rev. 396 (1947). But the language of the statute- "any funds borrowed or to be borrowed"-seems broad enough to include both types of transactions. PA. STAT. ANN., tit. 21, \$940.1 (Purdon, Cum. Supp. 1949). An installment buyer is as much a borrower as the man who pays cash for the goods and is later given a loan with the goods as collateral. That the General Assembly thought so is evidenced by the fact that at the session immediately succeeding enactment of the chattel mortgage statute it defined an installment sale contract to include one in which a mortgage is executed as security. Motor Vericle Sales Act of 1947, § 3(10), PA. STAT. ANN., tit. 69, §603(10) (Purdon, Cum. Supp. 1949).

6. The Pennsylvania version of the Uniform Conditional Sales Act does not affect bailment leases. Compare $\$ 1$ of the Uniform Act with PA. STAr. ANN., tit. 69, \$361 (Purdon, Cum. Supp. 1948). See Stern \& Co. v. Paul, 96 Pa. Super. 112 (1929). Whether a court will treat a particular transaction as a bailment is another matter. The cases are well analyzed by Maris, J. in Commercial Inv. Trust Co. v. Minon, 104 F.2d 765 (3d Cir. 1939). See, also, General Motors Acceptance Corp. v. Hartman, $114 \mathrm{~Pa}$. Super. 544, 174 Atl. 795 (1934).

7. Quinlan \& Robertson, Inc. v. Rundle, $273 \mathrm{~Pa} .479,117$ Atl. 208 (1922) ; cf. Mason \& Hamlin Co. v. Devon Manor School, 273 Pa. 398, 117 Atl. 78 (1922).

8. Brown v. Billington, $163 \mathrm{~Pa}$. 76, 29 Atl. 904 (1894); Clark v. Jack, 7 Watts 375 ( $\mathrm{Pa} .1838)$. 
tion of raw material or inventory by a manufacturer or retailer. But no matter how used, the same statutory rules are applicable, even though it cannot be said that these very much different situations raise the same problems. The Code, however, looks to the realities of a transaction, and the applicable rules are determined by an appraisal of those realities rather than by the form of the security device. The washing machine retailer need not record and may not insist that the purchaser waive rights growing out of breach of warranty. The holder of an inventory lien, on the other hand, must file a financing statement and his right to insist upon a waiver of contract rights is governed by Article 2 on Sales. It makes no difference under the Code that both security agreements are labeled "chattel mortgage."

\section{FILING}

Changes of little subtlety and immediate impact would be effected by the Code in the area of filing requirements and filing procedure. ${ }^{0}$ First of all, security devices arising from purchase money consumer goods transactions need not be filed at all, nor need there be filing for farm equipment purchases below a dollar amount to be filled in by the legislature. The question of whether consumer goods filing is worth the trouble and expense involved was really answered by the Pennsylvania courts more than a hundred years ago when they decided that a bailment lease, for which filing is not required, protects the lender's interest in the collateral against the debtor's creditors. While this provision may beget controversy in other jurisdictions, ${ }^{10}$ it is in reality no innovation for Pennsylvania. The Code merely extends the bailment lease rule to transactions which could have taken that form but which for reasons best known to the lender did not.

"Isolated" or "casual" assignments of accounts receivable are also exempted from the requirement of filing if a significant part of the assignor's accounts are not transferred. The present practice of stamping the assignor's books or notifying the account debtor ${ }^{11}$ would no longer be necessary.

For other non-possessory security interests, filing is required, and the Code adopts the notice filing system of the Uniform Trust Receipts Act and the Factor's Lien Act. A financing statement is effective for five years, ${ }^{12}$ whereas under existing statutes the duration varies from

9. $\$ 8-303$ enumerates the types of transaction for which filing is not required. Part 4 of Article $8, \S \S 8-401$ to $8-407$, provides for the formalities of filing.

10. The question of filing consumer goods transactions is discussed in Gilmore, Chattel Security: II, 57 Y ALE I.J, 761, 783-785 (1948); Kripke, The "Secured Transactions" Provisions of the Uniform Commercial Code, 35 VA. L. REv. 577, 612-613 (1949).

11. PA. Stat. ANN., tit. 69, §§561-562 (Purdon, Cum. Supp. 1948).

12. $\$ 8-405$. 
one to fifteen years, and as is now true of trust receipts, filing will generally be with the Secretary of State as well as in the county of the debtor's principal place of business. Farm equipment and farm product transactions are filed in the county of the debtor's residence, and when crops are to serve as collateral, the statement must also be filed with the Recorder of Deeds.

Code Section 8-401 (3) is in accord with the Pennsylvania decisions in providing that a financing statement which has in good faith been filed in the wrong place is nevertheless effective with regard to collateral as to which it is properly filed. ${ }^{13}$ Section $8-404$ provides that acceptance of the financing statement by the filing officer and payment of the fee affords complete protection to the lender. Of all the existing chattel security statutes, only the trust receipts act is so explicit on the risk of error problem, but the rule adopted is the one followed by the Pennsylvania courts, ${ }^{14}$ even in the absence of express statutory coverage.

A Code provision that may cause difficulty in Pennsylvania is Section 8-402. It exempts from the Article 8 filing requirements security interests in goods for which perfection, under some other statute, requires registration of the lien on a certificate of title. One such statute may be the Pennsylvania Vehicle Code, which provides that "A certificate of title shall contain . . . a statement of any liens or encumbrances" and that such notations "shall be adequate notice to the Commonwealth, creditors or purchasers that a lien . . exists." 15

The problem as it now exists is this: is a duly recorded conditional sale contract for a motor vehicle "perfected" if the vendor has failed to note his lien on the title certificate? The draftsmen of the chattel mortgage act recognized the problem and specifically provided that.a chattel mortgage on a motor vehicle is not perfected unless the lien is noted on the certificate. ${ }^{16}$ And there is one common pleas decision to the effect that a bailment lease of a motor vehicle is not perfected unless noted on the title certificate. ${ }^{17}$ If that case was rightly decided, then a security interest under any existing statute, and therefore under the Commercial Code, must be registered on the certificate if the lender is to be fully protected. This would be so even though an automobile may be consumer goods for which are exempted from

13. Oberholtzer's Appeal, 124 Pa. 583, 17 Atl. 143 (1889) ; Oberholtzer v. Evans, $134 \mathrm{~Pa} .366,19$ Atl. 681 (1890).

14. Glading v. Frick, 88 Pa. 460 (1879) ; Farabee v. McKerrihan, 172 Pa. 234, 33 At1. $583(1896)$.

15. Pa. Stat. AnN., tit. 75, $\$ 33$ (Purdon, Cum. Supp. 1948) (emphasis added).

16. PA. Stat. AnN., tit. 21, \$940.5 (Purdon, Cum. Supp. 1948). 1942).

17. General Motors Acceptance Corp. v. Colborn, 45 Pa. D. \& C. 82 (C.P. Lack. 
filing requirements under Commercial Code Section 8-303. And if registration on the certificate is "adequate notice to the Commonwealth, creditors and purchasers that a lien . . . exists," can a seller-lender safely ignore the provisions of all existing or future chattel security statutes and do no more than note his lien on the certificate? A plausible reading of the Vehicle Code is that notation of a lien on the certificate precludes the status of good faith purchaser or creditor to those who deal with the debtor. One thing, however, is very clear: unless the Vehicle Code is clarified, its want of clarity will be carried over into the Commercial Code. Lenders will be well advised now and even under the Commercial Code to file their security interests in motor vehicles with the Secretary of Revenue. ${ }^{17 a}$

\section{The Security Agreement}

A security agreement under the Code may be drafted so as to bind the debtor's after-acquired property. ${ }^{18}$ Indeed, Article 8 "pays little attention to rights of a borrower or lender between themselves. With few exceptions complete freedom to contract as to lender's rights is preserved." 19 There are exceptions, however, to the general sanction given to after-acquired property clauses when the collateral is crops or consumer goods. The Code follows the chattel mortgage act in barring liens on crops to be planted more than one year after the security agreement is made, ${ }^{20}$ but a tentative provision would permit after-acquired crop liens during the period of a lease, mortgage or land purchase contract if the security agreement is executed in conjunction with the real estate transaction. This tentative provision is by analogy, at least, consistent with the Pennsylvania "industrial mortgage" doctrine. ${ }^{21}$ The Code's prohibition, of after-acquired property clauses in consumer goods transactions replaces current provisions that previously purchased goods may secure subsequent purchases until the former goods are paid for. ${ }^{22}$

In the ordinary commercial security transaction, the Code places no limitations upon after-acquired property clauses. It is a matter for the parties to arrange to their own liking, as it is now under the

17a. On the general subject of reconciling the Vehicle Code with chattel security statutes, see Note, Toward the Standardization of Pennsylvania Motor Vehicle Liens, 98 U. OF PA. L. REv. 419 (1950).

18. $\S 8-203$.

19. Comment, \$ 8-101.

20. §8-203(a) ; Pa. Stat. Ans., tit. 21, §940.1 (Purdon, Cum. Supp. 1948).

21. See Roos v. Fairy Silk Mills, 334 Pa. 305, 5 A.2d 569 (1939).

22. PA. Stat. AnN., tit. 21, $\$ 940.4 a$ (chattel mortgage) ; tit. $69, \$ 409$ (conditional sale); tit. 69, § 511 (bailment lease) (Purdon, Cum. Supp. 1948). 
Factor's Lien Act. ${ }^{22 a}$ The present chattel mortgage statute, however, is more restrictive, for the lien of the mortgage can bind only afteracquired chattels of the same class, replacements and increase and produce of the collateral. The Code also permits the assignment of accounts receivable that have not yet accrued, with the lender's interest attaching when the account comes into existence. Before the enactment of the accounts receivable statute, it was held that accounts to accrue in the future were assignable. ${ }^{23}$ But under the current statute, only an "indebtedness" is assignable ${ }^{24}$ and although the courts have not yet spoken, it would seem that there can be no effective assignment until the assignor ships goods to the obligor and an obligation to pay for them is thereby created.

Pennsylvania's chattel security statutes make it clear that a security interest is not invalidated by the power of the debtor to sell or dispose of the collateral. ${ }^{24 a}$ Code Section $8-206$ is even more clear in laying down the same rule and goes one step further by burying the ghost of Benedict v. Ratner. ${ }^{25}$ In that case, the United States Supreme Court held that a security interest is invalid if the debtor does not account to the secured lender for the proceeds of sale of inventory or if the assignor of accounts receivable does not account to the lender for the collection of assigned accounts. The present assignment statute is silent in this respect and the question has never been litigated in a Pennsylvania state court. But there is a federal decision that the Pennsylvania rule is in accord with Benedict $v$. Ratner. ${ }^{26}$

When the parties to a transaction are all businessmen, Code Section 8-207, by reference to Article 2 on Sales, permits a seller to effectively disclaim express or implied warranties. ${ }^{27}$ In the case of assignments, an account debtor's agreement that he will not assert claims arising out of his contract with the assignor is enforceable by an

22a. Some difficulty may be attendant upon "floating liens" under the Factor's Lien Act because of its requirement of "separate statements." PA. STAT. ANN., tit. 6, $\$ 222$ (Purdon, Cum. Supp. 1949).

23. East Lewisburg Lumber \& Mfg. Co. v. Marsh, 91 Pa. 96 (1879).

24. Pa. Stat. AnN., tit. 69, $\$ 561$ (Purdon, Cum. Supp. 1948).

24a. This is not true, however, of the bailment lease, a non-statutory security device. A bailment lease is ineffective if the goods are intended for consumption or resale. Bowser \& Co. v. Franklin Mtge. \& Inv. Co., 305 Pa. 459, 158 Atl. 170 (1931); Hooveler-Stutz Co. v. Cleveland Motor Sales, $92 \mathrm{~Pa}$. Super. 425 (1928); cf. Brown v. Billington, $163 \mathrm{~Pa}$. 76, 29 Atl. 904 (1894) (trust receipt; trustee assimilated to bailee).

25. 168 U.S. 353 (1925).

26. In re Pusey, Maynes, Breish Co., 122 F.2d 606 (3d Cir. 1941).

27. \$2-316:

"(1) If the agreement creates an express warranty, words disclaiming it are inoperative.

"(2) Exclusion or modification of the implied warranty of merchantability or of fitness for a particular purpose must be in specific language and if the inclusion of such language creates an ambiguity in the contract as a whole it shall be resolved against the seller; . . ." 
assignee who takes his assignment for value and in good faith. However, defenses of a type which may be asserted against a holder in due course cannot be effectively waived. These ever-available defenses, as enumerated in Code Section 3-305, include infancy, incapacity, duress, illegality, fraud "in fact," and discharge in insolvency proceedings. But when a consumer comes into the picture, efforts to impart elements of negotiability to the security agreement are doomed to failure. Installment retailers will be compelled to abandon their favorite form of conditional sale contract, under which the vendee purports to promise not to assert any warranty defenses against an assignee. Although such contracts have long been in vogue, their effectiveness has not been passed upon by the Pennsylvania courts. In other jurisdictions, lenders have not fared too well with them, ${ }^{28}$ so it may be that Code Section 8-207 (3) does not in fact remove a weapon of any significance from the secured lender's armory. The Code also closes a side door to quasi-negotiability by invalidating negotiable notes which the consumer may execute as part of the security transaction. Heretofore, the side door was more than slightly ajar in Pennsylvania, for in Welton v. Littlejohn the Supreme Court held that a note imparted its negotiability to a contemporaneously executed real estate mortgage, cutting off the debtor's defenses on the mortgage as well as on the note. $^{20}$ The door has already been closed by the General Assembly as to motor vehicle security transactions, for a provision similar to Code Section 8-207 (3) is found in the Motor Vehicle Sales Finance Act of $1947 .{ }^{28 a}$

\section{Secured Lender v. Creditors and Purchasers}

As under current statutes, the secured lender who has not perfected his security interest by filing, when filing is necessary, is protected against the lender's creditors and purchasers only to the extent that they gave value or procured their liens with knowledge of the lender's interest. ${ }^{30}$ But even a perfected security interest is subject to defeat by buyers in the ordinary course of the debtor's trade when the debtor has been authorized by the security agreement to dispose of the collateral, which must be the case when the collateral is inventory. A perfected security interest in "chattel paper" 31 may also be defeated by a good faith assignee for value if the whole transac-

28. See Note, 57 Y ALE L.J. 1414 (1948). (1914).

29. $163 \mathrm{~Pa}$. 206, 29 Atl. 871 (1894); cf. Levy v. Gilligan, 244 Pa. 272, 90 Atl. 647

29a. Pa. Stat. Ann., tit. 69, \$615(G) (Purdon, Cum. Supp. 1949).

30. $\$ 8-301$.

31. \$ 8-106(4): " 'Chattel paper' means a writing which evidences a security interest in or a lease of goods, and which contains or secures a right to the payment of money, if the writing is of the type whose transfer customarily requires delivery. . .." 
tion is in the ordinary course of business, ${ }^{31 a}$ as is true under the Uniform Trust Receipts Act.

A security interest in after-acquired property-even though perfected-may be defeated by the holder of a subsequent purchase money security interest. ${ }^{32}$ Although this particular provision is new, the principle that purchase money obligations are to be accorded special treatment is by no means novel in Pennsylvania. Purchase money real estate mortgages, for example, are given precedence by statute. ${ }^{33}$ To merit special treatment under the Code, the purchase money lender must perfect his interest within ten days after the debtor receives the collateral, and if the collateral is inventory, the first lender must be given a detailed notice.

The question of whether goods in which the lender has a security interest have become fixtures is left by Code Section 8-112 to "other rules of law." But even if the collateral is a fixture under the Pennsylvania decisions, the secured lender's interest prevails over those of the realty owner or encumbrancer if he files with the Recorder of Deeds in addition to conforming with the general filing requirements of Article 8. The lender who has filed his interest with the custodian of the realty records may remove the collateral after default no matter how much it has become a part of the real estate. But he must reimburse the realty owner for physical damage caused by the removal. The rules laid down as to fixtures by current statutes are hardly changed at all, but the provision for filing security interests in fixtures with the realty records is new and quite sound. One provision of the conditional sales statute would seem worth adding to the Code. It permits the lender or realty owner to petition the court of common pleas for a determination of how great a bond should be posted to guard the realty owner against removal damages. ${ }^{34}$ This simple method of settling such disputes seems preferable to a full-blown lawsuit.

Security interests in accessions to chattels are treated by Code Section 8-313 much the same as fixtures. A perfected interest in the part added prevails over a prior perfected interest in the whole. Current statutes are silent on the subject of accessions to chattels, but it has been held that a prior interest in the principal chattel prevails against an interest in the accession unless the latter can be severed without detriment to the whole. ${ }^{35}$ The difficulty with this disarmingly

31a. $\$ 8-308$.

32. \& 8-311.

33. Pa. Stat. Ann., tit. $21, \S 622$ (Purdon, 1930).

34. Pa. Stat. Ann., tit. 69, $\$ 404$ (Purdon, Cum. Supp. 1948).

35. White Co. v. Bowen, 84 Pa. Super. 484 (1925). 
simple rule lies in determining which attachments can be severed without detriment to the principal chattel, and held so severable have been a truck body from a truck chasis ${ }^{36}$ and motor vehicle tires. ${ }^{37}$ If the accessions are severable, it does not seem to matter under the Pennsylvania decisions that the instrument retaining title to the whole purports to cover after-acquired accessories and replacement parts. ${ }^{38}$

Common law and statutory liens.-Two disturbing problems are raised in Pennsylvania by Code Section 8-309, which provides that:

If a person in the ordinary course of his business furnishes services or materials with respect to goods subject to a security interest, a lien given by statute or rule of law for such materials or services takes precedence over the security interest unless a statute creating the lien provides otherwise.

This section would apparently reverse the order of priority as between artisan and conditional vendor, for the conditional sales statute gives precedence to a lien creditor only if his lien arises by "attachment or levy," ${ }^{39}$ and that is not the genesis of an artisan's or carrier's lien. The same seems to hold true under the Chattel Mortgage Act. ${ }^{40}$ Opposite results flow from the language of the Uniform Trust Receipts Act and the Factor's Lien Act, with the common law or statutory lienor there prevailing over the secured lender. ${ }^{41}$ A reversal of priority is not of too much significance when, as with the conditional sale and the chattel mortgage, the change affects a clash of interests that does not frequently occur and when the secured lender's interest depends upon a chattel security statute of recent date.

It is the bailment lease and the Constitution of 1874 which raise the first Section 8-309 problem. To begin with, it is settled that a common law or statutory lien does not accrue to one who renders services to a bailee; no such lien may be asserted by the artisan or warehouseman against the bailor. ${ }^{42}$ The rationale of the leading case

36. White Co. v. Bowen, supra.

37. Goodrich Silvertown, Inc. v. Bryner, 42 Dauph. 267 (C.P. 1936) ; Worthington v. Jabs, 50 York 101 (C.P. 1936); National Tire \& Rubber Co. v. Daley's Blue Line Trans. Co., 28 Luzerne 6 (C.P. 1933). Cases from other jurisdictions are collected in Lee, Accessories to Automobiles Sold Under Title-Retaining Instrunnents, 19 TEMPLE L.Q. 89 (1945); Note, 92 A.L.R. 425 (1934).

38. Goodrich Silvertown, Inc. y. Bryner, supra; Worthington v. Jabs, supra; National Tire \& Rubber Co. v. Daley's Blue Line Trans. Co., supra.

39. Pa. Stat. Ann., tit. 69, $\$ 402$ (Purdon, 1931).

40. Pa. Stat. Anv., tit. 21, $\$ 940.5$ (Purdon, Cum. Supp. 1948).

41. PA. Stat. ANN., tit. 68, $\$ 561$ (Purdon, Cum. Supp. 1948) (trust receipt); tit. 6, \$224 (Purdon, Cum. Supp. 1948) (factor's lien).

42. Estey Co. v. Dick, $41 \mathrm{~Pa}$. Super. 610 (1910) (storage of piano) ; Stern v. Sica, $66 \mathrm{~Pa}$. Super. 84 (1917) (automobile mechanic) ; Bankers' Com. Sec. Co. v. Brennan v. Levy, $75 \mathrm{~Pa}$. Super. 199 (1920) (automobile mechanic). 
of Meyers v. Bratespeice is that there can be no lien unless the work is performed at the request of the person who has "title" to the collateral. ${ }^{43}$

If under the Code, a lender insists upon the bailment lease device in, for instance, the credit sale of an automobile and if the bailee-debtor takes the vehicle to an automobile mechanic for repairs, Section 8-309 would subordinate the interest of the bailor-lender to that of the mechanic. But the order of liens has always been just the opposite, and we have the constitutional provision which prohibits special or local laws providing or changing methods for the collection of debts and the enforcing of judgments, or authorizing the creation, extension or impairing of liens. ${ }^{44}$ This provision has been interpreted as freezing the law as it existed prior to $1874 . .^{45}$ Held invalid under it has been a statute giving an attorney a lien upon his client's cause of action, "an enactment radically different from any law existing before the date of its passage." 46 Also invalidated was a statute giving to certain silk processors a lien in the amount of any account due them upon goods which came into their hands for processing, even if such account had no relation to the particular goods against which the lien was asserted. ${ }^{47}$ On the other hand, more recent decisions have upheld similar statutes when "a real reason for the preference is made to appear." 48 "Real" reasons were found for giving priority to bank depositors in bank liquidation proceedings, ${ }^{49}$ for subordinating the interest of a real estate mortgagee to that of a conditional vendor, ${ }^{50}$ and for exempting a security interest in an ice cream cabinet from a landlord's distraint for rent. ${ }^{51}$ The cases taking the "freeze" point of view are distinguisable from the others only in result and in language, but certainly the public policy bases of the common law and statutory liens should be reason enough for the priority given them by Code Section 8-309.

The second problem raised by Section 8-309 is of much more substance and significance to lenders than the first. It involves, first of all, the question of whether a landlord's distraint for rent would take precedence over a Code security interest. It has long been the rule in Pennsylvania that goods held by a tenant under any type of security arrangement-including a bailment lease-are subject to a

43. $174 \mathrm{~Pa} .119,34$ At1. 551 (1896).

44. PA. Const. Art. $3, \S 7$.

45. Page v. Carr, 232 Pa. 371, 81 Atl. 430 (1911).

46. Laplacca v. Phila. Rapid Transit Co., 265 Pa. 304, 108 Atl. 612 (1919).

47. Gerli v. Perfect Silk Throwing Co., 70 Pa. Super. 299 (1918).

48. In re Cameron, 287 Pa. 560, 135 At1. 295 (1926).

49. In re Cameron, supra.

50. Ridgway Dynamo \& Engine Co. v. Werder, $287 \mathrm{~Pa} .358,135$ At1. 216 (1926).

51. Rieck-McJunkin Dairy Co. v. Sachs Real Estate Co., 102 Pa. Super. 293, 156 Atl. 748 (1931). 
landlord's distraint for rent. ${ }^{52}$ In view of these cases, it seems probable that a landlord is a person "who in the ordinary course of his business furnishes services" to goods kept on the rented premises. If the courts so hold, it will be necessary to reconcile with the Code a heterodoxy of statutes which exempt from distraint collateral ranging from melódeons through household goods to dynamos. ${ }^{53}$ The language of these statutory monuments to trade association lobbies is fully as diverse as the types of goods they exempt, and the prudent lender must study the applicable one carefully before deciding upon the form of security device employed. For the story of a lender who was not so prudent, see Commercial Credit Plan v. Mahoney. ${ }^{54}$ There, household goods were sold to a tenant subject to a duly perfected chattel mortgage, but the exemption statute for household goods provides that the collateral is not liable to distraint if "leased or hired under bailment lease . . . or conditionally sold." 55 The outcome was that the secured lender lost out to the landlord. Should this decision be followed, form might retain importance even under the Commercial Code. To avoid such an unfortunate result, it is suggested that the exemption statutes be revised to protect any security interest in the designated types of collateral.

\section{Rights ON Default}

The rights of a secured lender on default, as indexed by Code Section 8-501, are roughly equivalent to those which exist under the current statutes. Under this section the lender may repossess without judicial assistance if he can do so peaceably, but if consumer goods are involved and if the debtor has paid more than sixty per cent of the secured obligation, then the lender must give at least twenty days notice of his intention to repossess. As under the Conditional Sales Act, ${ }^{56}$ the lender may keep the collateral in satisfaction of his interest by notifying the debtor that he intends to do so and if the debtor does not object within twenty days. ${ }^{57}$

In its establishment of procedure for sale by the lender of the repossessed collateral, the Code takes a middle path between the cumbersome and expensive restrictions of the Conditional Sales Act and the utter freedom of action given the lender in a bailment lease trans-

52. Reinhart v. Gerhardt, 152 Pa. Super. 229, 31 A.2d 737 (1943) ; National Cash Register Co. v. Ansell, $125 \mathrm{~Pa}$. Super. 309, 189 At1. 738 (1937).

53. The exemption statutes appear in PA. Stat. ANN., tit. 12, $\$ \$ 2169-2180$ (Purdon, 1931; Cum. Supp. 1948).

54. 57 Pa. D. \& C. 577 (C.P. Erie 1948).

55. Pa. Stat. Ann., tit. 12, \$2178 (Purdon, Cum. Supp. 1948).

56. Pa. STAT. ANN., tit. 69, \$ 458 (Purdon, 1931).

57. §8-505. 
action. Under the Code the sale may be either public or private. All that is required is that it be conducted in a "commercially reasonable manner" 58 and that "reasonable" notice be given to interested parties. This is in sharp contrast to the Conditional Sales Act, which requires a public sale within thirty days if the debtor has paid at least fifty per cent of the purchase price, the posting of three notices of sale in the filing district and advertising if the debtor has paid more than $\$ 500.59$ Private sales are now permitted, however, when the security device employed is a chattel mortgage ${ }^{60}$ or trust receipt. ${ }^{61}$ Strangely, the Factor's Lien Act makes no provision at all for either repossession or sale on default.

The code also provides that, unless the debtor has renounced his right of redemption or the lender has given notice of his intention to keep the collateral, the debtor may reclaim the goods at any time before a contract of sale has been executed by tendering expenses and all sums due under the defaulted agreement. ${ }^{62}$ This redemption provision is similar to that in the chattel mortgage statute. ${ }^{63}$ However, under the Conditional Sales Act, a vendee who has not been given notice of the lender's intention to repossess may redeem the collateral in ten days by paying merely the expenses of repossession and the amount due under the contract at the time of repossession. ${ }^{64}$

A new provision is Code Section 8-502, which gives to the assignee of accounts receivable or chattel paper the right to complete control of the assigned accounts when the assignor is in default. But if the assignment was "with recourse," the assignee must proceed in a commercially reasonable manner.

\section{Concluston}

No attempt has been made in this paper to touch upon every aspect of the Code as it deals with secured transactions, nor does the discussion purport to note every change which would be effected by the Code in the Pennsylvania law of chattel security. An attempt has been made, however, to note those Code provisions which should prove to be of greatest significance to Pennsylvania businessmen and lawyers. Should the Code be adopted by the General Assembly, future events will undoubtedly disclose problems which were not anticipated here or by the Code's draftsmen. But it is apparent from a study of

58. § 8-507.

59. PA. Stat. Ann., tit. 69, § 455 (Purdon, 1931).

60. Pa. Stat. ANN., tit. 21, \$940.14 (Purdon, Cum. Supp. 1948).

61. Pa. Stat. Ann., tit. 68, § 556 (Purdon, Cum. Supp. 1948).

62. § 8-506.

63. Pa. Stat. Ann., tit. 21, §940.14(c) (Purdon, Cum. Supp. 1948).

64. Pa. Stat. AnN., tit. 69, $\$ \$ 452,453$ (Purdon, 1931). 
the Code that its draftsmanship is superbly clear and precise; insofar as precision of language can bring certainty to the rules governing chattel security, the Code will do just that. The improvement it promises over Pennsylvania's current array of chattel security statutes is much more, however, than precision of draftsmanship. The rules it lays down are well calculated to meet every legitimate need of the business community. For the most part, they are modeled after concepts that have already been proved and tested in the laboratory of commercial experience. Those provisions which are new seem to follow from those which have been proved and tested. And for the first time, these rules have been assembled into an integrated statute that will permit courts as well as lawyers to base their judgments upon facts instead of form. 